\title{
High Baseline Serum Clara Cell 16 kDa Predicts Subsequent Lung Disease Worsening in Systemic Sclerosis
}

\author{
Sébastien Rivière, Thong Hua-Huy, Kiet Phong Tiev, Jean Cabane, and Anh Tuan Dinh-Xuan
}

ABSTRACT. Objective. Clara cell secretory protein (CC16) is a sensitive marker of bronchial epithelial cell damage.
The CC16 serum level is elevated in patients with pulmonary fibrosis, but its predictive value on lung
disease progression has not yet been studied. We aimed to assess the value of serum CC16 concen-
tration in predicting lung disease deterioration in patients with systemic sclerosis (SSc).
Methods. We prospectively analyzed and followed 106 patients with SSc during a 4 -year period for
the risk of developing combined deleterious event, defined as a $10 \%$ decrease in total lung capacity
or forced vital capacity from baseline, or death, according to serum CC16 at inclusion.
Receiver-operating characteristic (ROC) curve analysis was performed for prediction of events during
the first 2 years after inclusion. Cumulative risks of combined events were computed by Kaplan-Meier
analysis.
Results. The best cutoff level of serum CC16 for prediction of a combined event was 33 ng/ml, with
76\% sensitivity and $65 \%$ specificity (area under the ROC curve: $0.71,95 \%$ CI $0.61-0.81, \mathrm{p}<0.0001)$.
Progression of lung disease evaluated by a mean time-to-event differed between patients with high
baseline serum CC16 (42.8 mos, $36.3-49.3$ ) and those with low serum CC16 (56.3 mos, 50.9-61.7;
log-rank test, p 0.001 ). After adjustment for age, duration of disease, clinical and lung function
measures, the risk of combined event occurrence in patients with high serum CC16 was significantly
higher than in those with low CC16 (HR 2.9, 1.2-6.75, p < 0.05).

Conclusion. High baseline serum CC16 predicts lung disease worsening in patients with SSc. (First Release November 15 2017; J Rheumatol 2018;45:242-7; doi:10.3899/jrheum.170440)

\section{Key Indexing Terms: \\ SYSTEMIC SCLEROSIS \\ CLARA CELL SECRETORY PROTEIN}

Systemic sclerosis (SSc) is a life-threatening disease characterized by immune system activation, microvascular injuries, and excessive production of collagen, resulting in skin and internal organ fibrosis ${ }^{1}$. Interstitial lung disease (ILD) is frequently encountered and is currently the leading cause of mortality in $\mathrm{SSc}^{2}$. The pathophysiology of SSc is complex and not fully understood ${ }^{3}$. Current therapeutic strategies, based on immunosuppressive agents, showed only modest

From the Internal Medicine Department, AP-HP Saint-Antoine Hospital, Pierre and Marie Curie University; Physiology Department, AP-HP Cochin Hospital, Paris Descartes University, Sorbonne Paris Cité, Paris; Unité de Médecine Interne, Hôpital Pasteur, Vitry-sur-Seine, France.

Supported by grants from the Legs Poix, University of Paris, and the Air Liquide Foundation.

S. Rivière, MD, Internal Medicine Department, AP-HP Saint-Antoine Hospital, Pierre and Marie Curie University; T. Hua-Huy, MD, PhD, Physiology Department, AP-HP Cochin Hospital, Paris Descartes University, Sorbonne Paris Cité; K.P. Tiev, MD, PhD, Unité de Médecine Interne, Hôpital Pasteur; J. Cabane, MD, Internal Medicine Department, AP-HP Saint-Antoine Hospital, Pierre and Marie Curie University; A.T. Dinh-Xuan, MD, PhD, Physiology Department, AP-HP Cochin Hospital, Paris Descartes University, Sorbonne Paris Cité.

Address correspondence to Dr. A.T. Dinh-Xuan, 27 rue Faubourg

Saint-Jacques, 75679 Paris Cedex 14, France.

E-mail: anh-tuan.dinh-xuan@aphp.fr

Accepted for publication September 1, 2017.

\section{INTERSTITIAL LUNG DISEASE LUNG FUNCTION PROGNOSIS}

efficacy ${ }^{4}$. However, SSc patients with severe or worsening ILD may benefit greatly from such treatments ${ }^{5,6}$. It is important to identify patients at risk for lung function deterioration, for whom early therapy may reduce lung damage. Various autoantibody subsets, including anti-topoisomerase I (anti-topo I) and centromere antibodies, can identify patients with SSc who will likely develop SSc-related ILD and pulmonary arterial hypertension, respectively $7,8,9$. There is, however, only a very small number of studies investigating longterm predictors of ILD progression in $\mathrm{SSc}^{10,11}$.

Among lung-specific secretory proteins, also named pneumoproteins, Clara cell $16 \mathrm{kDa}$ (CC16), secreted by bronchiolar Clara cells or Club cells, is one of the most abundant pneumoproteins. Its physiological role is incompletely known, but it may participate in bronchial epithelium defense mechanisms against oxidative stress and inflammation $^{12}$. In acute or chronic lung injuries, CC16 was secreted into bronchoalveolar lavage fluid and rapidly leaked into the bloodstream because of its small size and molecular weight. Thus, serum CC16 can be used as a biomarker of lung diseases reflecting the lung epithelial damage ${ }^{12}$. Serum CC16 concentration was increased in idiopathic pulmonary fibrosis ${ }^{13}$ and sarcoidosis ${ }^{14}$, but decreased in smokers ${ }^{15}$ and patients with chronic obstructive pulmonary disease ${ }^{13,16}$. In

Personal non-commercial use only. The Journal of Rheumatology Copyright (C) 2018. All rights reserved. 
their retrospective study of 92 patients with SSc, Hasegawa, et al found higher serum CC16 levels in patients with pulmonary fibrosis than in those without pulmonary fibrosis ${ }^{17}$. The result was recently confirmed by a Polish report in a small group of patients with SSc having extended pulmonary fibrosis, defined as high-resolution computed tomography (HRCT) with an extent of more than $20 \%{ }^{18}$. However, there was no report investigating the predictive value of $\mathrm{CC} 16$ on the occurrence of lung function decline in patients with SSc.

We hypothesized that an increase in serum CC16 levels is a potential noninvasive marker of alveolar-capillary barrier disruption, reflecting early damage to the lungs in SSc. We therefore undertook this prospective study to determine the value of serum CC16 as a predictive marker of subsequent lung function deterioration in patients with SSc.

\section{MATERIALS AND METHODS}

The present study was approved by the Ethics Committees of Ile-de-France (approval number 05654). All patients had been informed about the study and signed the consent form.

Patients. Enrollment was conducted from January 2005 and November 2009 in the Department of Internal Medicine, Saint-Antoine Hospital (Paris, France), and the followup of this time-to-event-driven study ended in May 2012. Patients were considered for inclusion if they were aged $\geq 18$ years and had SSc as defined by the American College of Rheumatology criteria ${ }^{19}$. Exclusion criteria were the presence of recent upper airway tract infection, pneumonia, or other systemic infection in the 3 months prior to the study; asthma; chronic obstructive pulmonary disease; idiopathic pulmonary fibrosis or ILD associated with connective tissue diseases other than SSc and creatinine clearance inferior to $30 \mathrm{ml} / \mathrm{min} / 1.73 \mathrm{~m}^{2}$, according to the Modification of Diet in Renal Disease Study equation.

Study design. At the time of inclusion, these data were recorded: demographic data, duration of disease (delay between the first symptom attributable for SSc and the inclusion date), subset of SSc, modified Rodnan skin score (mRSS), autoantibody status including anticentromere (ACA) and anti-topo I antibodies, and Health Assessment Questionnaire (HAQ). All patients underwent thoracic HRCT, pulmonary function test (PFT), and echocardiography. PFT were routinely performed according to the American Thoracic Society and the European Respiratory Society (ATS/ERS) recommendations ${ }^{20}$. ILD was considered present if pulmonary HRCT demonstrated compatible changes in reticular or airspace opacities according to ATS/ERS consensus classification ${ }^{21}$.

The endpoint was the occurrence of combined deleterious events, defined as a $10 \%$ decrease in total lung capacity (TLC) or forced vital capacity (FVC) from baseline, or death ${ }^{22}$. The rationale for using these criteria as final outcome was first because pulmonary fibrosis is actually the most frequent cause of mortality (19\%) in $\mathrm{SSc}^{2}$. Second, the cutoff value of $10 \%$ decrease in TLC or FVC was generally accepted as strong evidence of disease progression in pulmonary fibrosis ${ }^{22,23}$.

Survival data were obtained from visits and telephone interviews. Patients were annually evaluated by PFT, chest HRCT, and echocardiography (or earlier in an additional visit if symptoms appeared). Patients who had not been seen within 6 months were called to confirm their vitality.

Measurement of serum CC16 concentrations. Serum CC16 was quantified using Human Uteroglobulin Quantikine ELISA kits (DUGB00, R\&D Systems Europe). All serum samples were diluted to 1:4. All samples were assayed in duplicate. Intraassay coefficients of variation of $<10 \%$ were accepted

Statistical analysis. First, we assessed the optimal threshold and the diagnostic performance of $\mathrm{CC} 16$ for identifying patients with SSc who were going to have a combined deleterious event within the 2 years after inclusion by using receiver-operating characteristic (ROC) curve analysis. We used the 1000 bootstraps technique for internal validation.

Second, patients with SSc were equally categorized into 2 groups: patients with a serum CC16 level higher than the optimal threshold, and other patients. Characteristics for the group of SSc patients with serum CC16 $\leq$ optimal cutoff versus those with greater levels of serum CC16 were compared using Mann-Whitney $U$ tests for continuous variables and chi-square tests for categorical variables. Continuous and categorical values are presented as mean $\pm \mathrm{SD}$ and number (\%), respectively. A $\mathrm{p}$ value of $<0.05$ was considered statistically significant.

To estimate the predictive value of serum $\mathrm{CC} 16$ on lung function outcomes during the whole followup period, cumulative risks were computed by Kaplan-Meier analysis. We first conducted unadjusted Cox analyses according to each baseline characteristic separately. A multivariable Cox model further adjusted CC16 as categorical variable for age, FVC, DLCO, and serum creatinine as continuous variables, and smoking status, the presence of ILD, and immunosuppressive therapy as categorical variables.

\section{RESULTS}

Population characteristics. The study included 106 patients. Their mean age was $55.4 \pm 12.7$ years with SSc duration of $13.2 \pm 12.6$ years at inclusion (ranging from 10 mos to 58 yrs), and $89 \%$ were women. One-third of patients had diffuse cutaneous SSc and half of patients had ILD. Eighteen of the 106 patients received immunosuppressive therapies (cyclophosphamide, $\mathrm{n}=4$; azathioprine, $\mathrm{n}=1$; mycophenolate mofetil, $\mathrm{n}=6$; methotrexate, $\mathrm{n}=6$; corticosteroids $\geq 10 \mathrm{mg}$ daily, $\mathrm{n}=10$; tacrolimus, $\mathrm{n}=2$ ). During the mean followup of $46 \pm 20$ months, 5 patients died. The composite event (10\% decrease in TLC or FVC from baseline, or death) occurred in 41 patients (39\%).

Measurement of baseline serum CC16 was performed in 106 patients and the results were presented in a scatter plot (Figure 1) according to the limited and diffuse cutaneous subtypes of SSc. There was no significant difference in serum CC16 levels between the 2 groups (diffuse form: $\mathrm{n}=37,43$ $\pm 28 \mathrm{ng} / \mathrm{ml}$ and limited: $\mathrm{n}=69,48 \pm 39 \mathrm{ng} / \mathrm{ml} ; \mathrm{p}=0.8)$.

ROC curve analysis. The area under the ROC curve of serum $\mathrm{CC} 16$ for prediction of occurrence of the combined events was 0.71 (95\% CI $0.61-0.81, \mathrm{p}<0.0001)$. The best cutoff level was $33 \mathrm{ng} / \mathrm{ml}$ (95\% CI 18.9-50.7) with sensitivity, specificity, positive predictive value, and negative predictive value of 0.76 (95\% CI $0.6-0.88$ ), 0.65 (95\% CI 0.5-0.76), 0.57 (95\% CI 0.43-0.7), 0.81 (95\% CI 0.67-0.9), respectively.

Characteristics of SSc population according to the best cutoff of serum CC16. Patients in the group with serum CC16>33 $\mathrm{ng} / \mathrm{ml}$ were older $(59.4 \pm 11.6$ vs $51.4 \pm 12.5 \mathrm{yrs} ; \mathrm{p}<0.01)$ and had higher serum creatinine level $(87 \pm 22$ vs $76 \pm 12$ $\mu \mathrm{mol} / \mathrm{l} ; \mathrm{p}=0.01$ ). No statistically significant difference was seen between the 2 populations concerning sex ratio, duration of SSc disease, diffuse cutaneous SSc, mRSS, HAQ score, presence of ILD, FVC, TLC, DLCO, systolic pulmonary arterial pressure, smoking status, presence of ACA and anti-topo I antibodies, and immunosuppressive therapy (Table 1). The combined event occurred in 30 patients (57\%) Personal non-commercial use only. The Journal of Rheumatology Copyright @ 2018 . All rights reserved. 


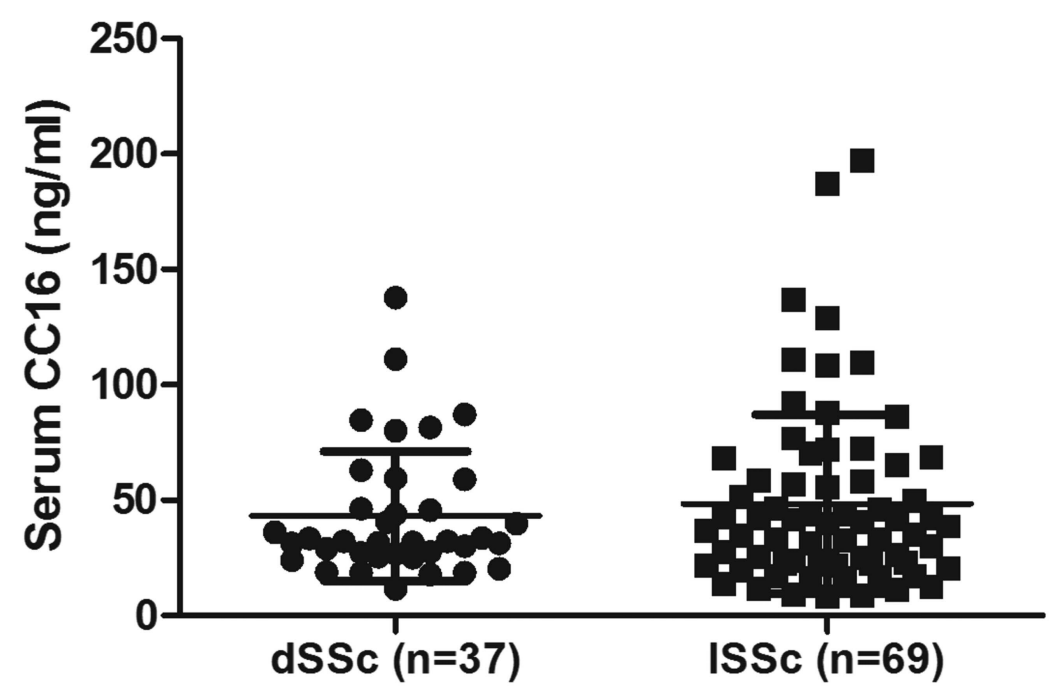

Figure 1. Comparison of baseline serum Clara cell $16 \mathrm{kDa}(\mathrm{CC} 16)$ levels in patients with systemic sclerosis $(\mathrm{SSc})$ between diffuse $(\mathrm{dSSc})$ and limited $(\mathrm{ISSc})$ cutaneous subtypes. No significant difference has been found ( $\mathrm{p}=0.8$ by Mann-Whitney $\mathrm{U}$ test) in serum CC16 levels between the 2 groups (dSSc: $\mathrm{n}=37,43 \pm 28 \mathrm{ng} / \mathrm{ml}$ and $1 \mathrm{SSc}: \mathrm{n}=69,48 \pm 39 \mathrm{ng} / \mathrm{ml}$ ).

Table 1. Baseline characteristics of patients with SSc. Values are $\mathrm{n}(\%)$ or mean $\pm \mathrm{SD}$.

\begin{tabular}{lcccc}
\hline Characteristics & $\begin{array}{c}\text { All Patients, } \\
\mathrm{n}=106\end{array}$ & $\begin{array}{c}\mathrm{CC} 16 \leq 33 \mathrm{ng} / \mathrm{ml}, \\
\mathrm{n}=53\end{array}$ & $\begin{array}{c}\mathrm{CC} 16>33 \mathrm{ng} / \mathrm{ml}, \\
\mathrm{n}=53\end{array}$ & $\mathrm{p}$ \\
\hline Age, yrs & $55.4 \pm 12.7$ & $51.4 \pm 12.5$ & $59.4 \pm 11.6$ & $<0.01$ \\
Female sex & $94(89)$ & $47(89)$ & $47(89)$ & $\mathrm{ns}$ \\
Duration of SSc, yrs & $13.2 \pm 12.6$ & $11.5 \pm 11$ & $14.9 \pm 13.9$ & $\mathrm{~ns}$ \\
dcSSc & $37(35)$ & $23(43)$ & $14(26)$ & $\mathrm{ns}$ \\
mRSS & $8.6 \pm 7$ & $7.5 \pm 5.5$ & $9.6 \pm 8.2$ & $\mathrm{~ns}$ \\
HAQ & $0.77 \pm 0.75$ & $0.73 \pm 0.7$ & $0.8 \pm 0.8$ & $\mathrm{~ns}$ \\
ILD & $56(52.8)$ & $27(51)$ & $29(55)$ & $\mathrm{ns}$ \\
FVC & $96 \pm 21$ & $95 \pm 22$ & $96 \pm 21$ & $\mathrm{~ns}$ \\
TLC & $96 \pm 17$ & $98 \pm 16$ & $94 \pm 17$ & $\mathrm{~ns}$ \\
DLCO & $62 \pm 16$ & $65 \pm 16$ & $59 \pm 16$ & $\mathrm{~ns}$ \\
Systolic PAP, mmHg & $34 \pm 8$ & $33 \pm 6$ & $36 \pm 9$ & $\mathrm{~ns}$ \\
Current smokers & $24(22.6)$ & $15(28)$ & $9(17)$ & 0.54 \\
Serum creatinine, $\mu$ mol/1 & $82 \pm 18$ & $76 \pm 12$ & $87 \pm 22$ & 0.01 \\
ACA & $48(45)$ & $21(39)$ & $27(51)$ & 0.33 \\
Anti-topo I & $29(27)$ & $17(32)$ & $12(23)$ & 0.38 \\
Immunosuppressive therapy & $18(17)$ & $12(23)$ & $6(11)$ & 0.19 \\
\hline
\end{tabular}

\footnotetext{
* Assessed by echocardiography. CC16: Clara cell 16 kDa; SSc: systemic sclerosis; HAQ: Health Assessment Questionnaire; ILD: interstitial lung disease; FVC: forced vital capacity; TLC: total lung capacity; PAP: pulmonary arterial pressure; dcSSc: diffuse cutaneous SSc; mRSS: modified Rodnan skin score; ACA: anticentromere antibodies; anti-topo I: antitopoisomerase I antibodies; ns: nonsignificant.
}

in the group with serum $\mathrm{CC} 16>33 \mathrm{ng} / \mathrm{ml}$ and in 11 patients $(2 \%)$ in the group with serum $\mathrm{CC} 16 \leq 33 \mathrm{ng} / \mathrm{ml}$.

Association between serum CC16 level at baseline and subsequent deterioration in lung function or death. Progression of lung disease differed between patients with high and low baseline serum CC16 (Figure 2), with a mean time to event of 42.8 months (95\% CI 36.3-49.3) and 56.3 months (95\% CI 50.9-61.7), respectively (log-rank test; $\mathrm{p}<0.001)$.

In an unadjusted Cox model (Table 2), serum CC16 > 33 $\mathrm{ng} / \mathrm{ml}$ had a predictive value for lung function deterioration, with HR of 3.14 (95\% CI 1.57-6.27, p < 0.01). The other baseline characteristics associated with lung function worsening were mRSS (HR 1.04, 95\% CI 1-1.08, p <0.05), 


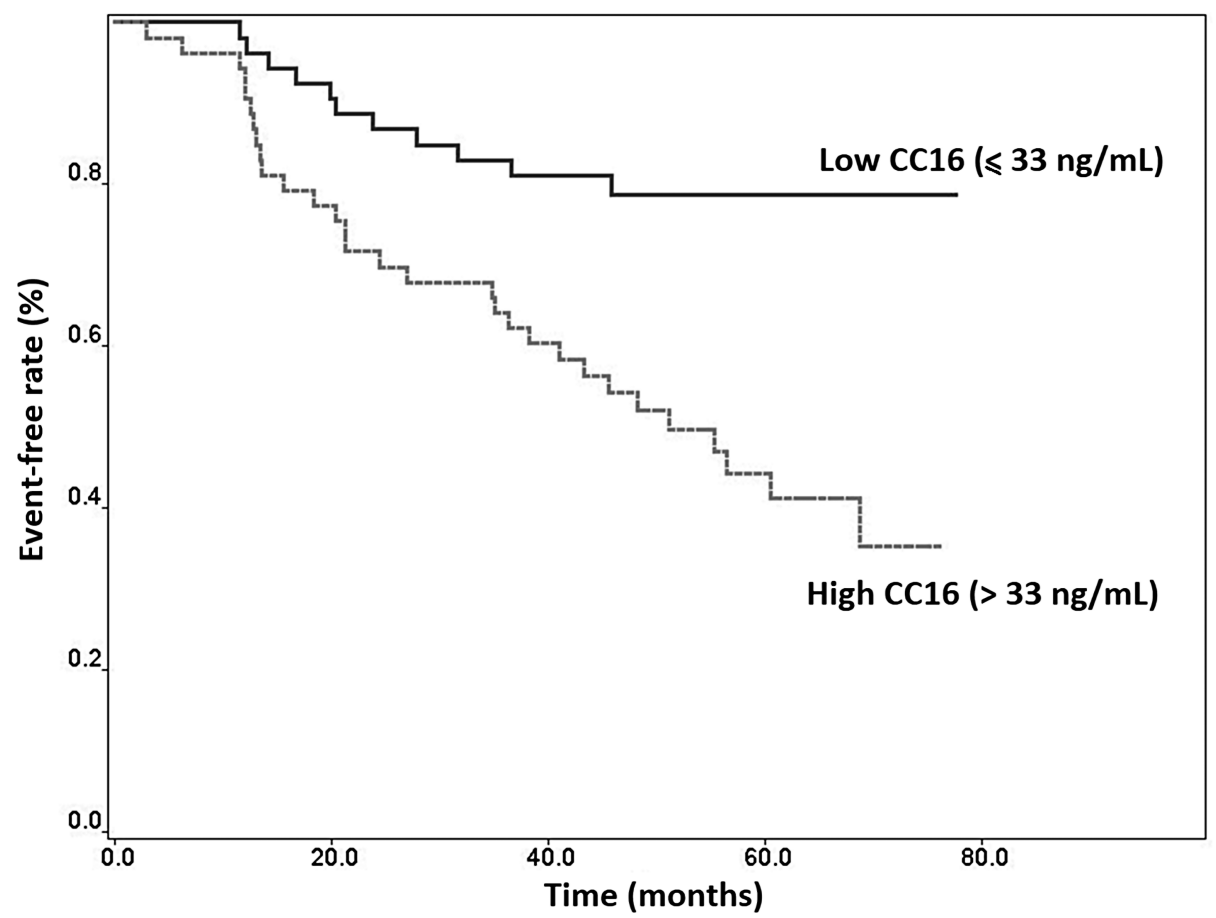

Figure 2. Kaplan-Meier survival analysis grouped by baseline serum Clara cell $16 \mathrm{kDa}(\mathrm{CC} 16)$ concentration according to the best cutoff to predict deterioration in lung function or death 2 years after inclusion in the study. The continuous black line represents patients with systemic sclerosis (SSc) with serum CC16 $\leq 33 \mathrm{ng} / \mathrm{ml}$ $(\mathrm{n}=53)$, and the broken grey line represents SSc patients with serum CC16>33 ng/ml. Patients with SSc with serum CC16 $>33 \mathrm{ng} / \mathrm{ml}(\mathrm{n}=53)$ were more likely to develop lung function deterioration or death than other patients $(\mathrm{p}<0.001)$.

ILD (HR 2.11, 95\% CI 1.49-3.89, $\mathrm{p}<0.05$ ), and serum creatinine (HR $1.01,95 \%$ CI $1-1.03, \mathrm{p}<0.05)$.

Table 2. Univariate analysis assessing the rate of lung disease worsening in patients with SSc.

\begin{tabular}{lcc}
\hline Variables & HR $(95 \%$ CI $)$ & $\mathrm{p}$ \\
\hline CC16>33 ng/ml* & $3.14(1.57-6.27)$ & $<0.01$ \\
Age, as continuous variable, per yr & $1(0.98-1.03)$ & $\mathrm{ns}$ \\
Current smoker* & $0.92(0.44-1.94)$ & $\mathrm{ns}$ \\
Duration of SSc, as continuous variable, & & \\
$\quad$ per yr & $0.99(0.97-1.02)$ & $\mathrm{ns}$ \\
mRSS, as continuous variable & $1.04(1-1.08)$ & $<0.05$ \\
FVC, as continuous variable, per \% & $0.99(0.98-1)$ & $\mathrm{ns}$ \\
TLC, as continuous variable, per \% & $0.99(0.98-1.01)$ & $\mathrm{ns}$ \\
DLCO, as continuous variable, per \%\# & $0.98(0.96-1)$ & $\mathrm{ns}$ \\
ILD* & $2.11(1.49-3.89)$ & $<0.05$ \\
IS* & $1.34(0.62-2.92)$ & $\mathrm{ns}$ \\
Systolic PAP, as continuous variable, & $1.03(1-1.06)$ & $\mathrm{ns}$ \\
$\quad$ per mmHg & & \\
Serum creatinine, as continuous variable, & $1.01(1-1.03)$ & $<0.05$ \\
$\quad$ per $\mu$ mol/l & &
\end{tabular}

* As categorical variable. ${ }^{\#}$ Proportion of predicted value. SSc: systemic sclerosis; CC16: Clara cell 16 kDa; FVC: forced vital capacity; TLC: total lung capacity; ILD: interstitial lung disease; IS: immunosuppressive therapy; PAP: pulmonary arterial pressure; mRSS: modified Rodnan skin score; ns: nonsignificant.
In the Cox proportional hazards model adjusted for age, duration of SSc, mRSS, smoking status, FVC, DLCO, presence of ILD, immunosuppressive therapy, and serum creatinine (Table 3), patients with baseline serum CC16 $>33$ $\mathrm{ng} / \mathrm{ml}$ had a higher risk of combined event occurrence (HR $2.9,95 \%$ CI 1.2-6.75; $\mathrm{p}<0.05)$.

Table 3. Multivariate analysis (Cox proportional hazards model) assessing the rate of lung disease worsening in patients with SSc.

\begin{tabular}{lcc}
\hline Variables & HR $(95 \%$ CI $)$ & $\mathrm{p}$ \\
\hline CC16>33 ng/ml * & $2.9(1.2-6.75)$ & $<0.05$ \\
Age (as continuous variable, per yr) & $0.99(0.96-1.02)$ & $\mathrm{ns}$ \\
Current smoker* & $0.99(0.42-2.35)$ & $\mathrm{ns}$ \\
Duration of SSc, as continuous variable, & & \\
$\quad$ per yr & $0.98(0.94-1.02)$ & $\mathrm{ns}$ \\
mRSS, as continuous variable & $1.01(0.96-1.07)$ & $\mathrm{ns}$ \\
FVC, as continuous variable, per \% ${ }^{\#}$ & $1(0.98-1.03)$ & $\mathrm{ns}$ \\
DLCO, as continuous variable, per \% & $0.99(0.97-1.02)$ & $\mathrm{ns}$ \\
ILD* & $1.63(0.72-3.69)$ & $\mathrm{ns}$ \\
IS* & $1.63(0.53-3.6)$ & $\mathrm{ns}$ \\
Serum creatinine, as continuous variable, & & \\
$\quad$ per $\mu$ mol/1 & $1(0.99-1.02)$ & $\mathrm{ns}$ \\
\end{tabular}

*As categorical variable. \# Proportion of predicted value. CC16: Clara cell 16 kDa; SSc: systemic sclerosis; mRSS: modified Rodnan skin score; FVC: forced vital capacity; ILD: interstitial lung disease; IS: immunosuppressive therapy. 


\section{DISCUSSION}

In this prospective cohort study, we show that elevated serum $\mathrm{CC} 16>33 \mathrm{ng} / \mathrm{ml}$ is a predictive marker of subsequent lung function deterioration or death in patients with SSc. Reliable markers of ILD outcome are currently lacking in patients with SSc. Pulmonary function tests are used in daily practice, but Assassi, et $a l^{24}$ showed that baseline FVC is not a predictive marker of subsequent decline in percentage predicted FVC over time. Because of their specificity to the lungs, pneumoproteins are potential markers of ILD in patients with SSc. Studies of surfactant protein D and Krebs von den Lungen-6 suggested that their elevation in serum could be a marker of ILD ${ }^{25}$. Reports evaluating the predictive value of CC Chemokine-ligand 18 for detecting lung disease worsening in patients with $\mathrm{SSc}$, however, yielded conflicting results 11,26 .

CC16 is a small pneumoprotein and is a sensitive marker of damage to the epithelium of the lungs ${ }^{12}$. We, therefore, hypothesized that elevation of serum CC16 could identify damage to the lungs that leads to lung function worsening in patients with SSc. To date, only 1 retrospective study has shown that elevated serum $\mathrm{CC} 16$ was associated with pulmonary fibrosis in patients with SSc and that serum CC16 increased significantly in patients with active pulmonary fibrosis, as defined by HRCT worsening and PFT decline during the 1-year followup ${ }^{17}$. A more recent study of 28 patients with SSc showed that serum CC16 was correlated with the severity of SSc-related ILD as assessed by HRCT and $\mathrm{PFT}^{18}$. None of these reports considered the predictive value of this novel biomarker in the progression of SSc-related ILD. Our prospective study with longterm followup (around $4 \mathrm{yrs}$ ) is the first, to our knowledge, to show that high baseline serum CC16 predicts lung disease aggravation in patients with SSc. This predictive power is independent of baseline characteristics such as age, smoking status, disease duration and severity at baseline, including PFT measures (FVC, DLCO) and presence of parenchymal lesions revealed on chest HRCT.

Intravascular leakage through damaged lung epithelium can directly influence serum CC16 concentration, but other mechanisms might also account for changes in $\mathrm{CC} 16$ levels in patients with $\mathrm{SSc}^{12}$. Owing to its low molecular weight, CC16 is eliminated by glomerular filtration, and renal insufficiency can lead to elevation in serum $\mathrm{CC} 16^{17}$. Patients with severe kidney disease were thus excluded from this study. Tobacco smoking has been shown to decrease production of CC16 in the respiratory tract, resulting in lower serum CC16 ${ }^{15,16}$. Smoking status was available for all patients included in our study. We included tobacco smoking and serum creatinine in our multivariate analysis and showed that high serum CC16 predicts lung disease worsening independently of these 2 variables. Overall, 41 patients (39\%) met the composite events, including 10 deaths $(9.4 \%)$, during the followup period. Our hospital is one of the national reference centers for SSc, usually receiving patients with severe SSc, which can explain in part the high rate of combined events.

We were unable to avoid some limitations when conducting our study. First, our study population had relatively longstanding disease, and it would be interesting to investigate the usefulness of CC16 in patients with newly diagnosed SSc. Second, we used internal validation to show the robustness of $\mathrm{CC} 16$ threshold for prediction of lung disease worsening. External validation in an independent cohort is needed before serum CC16 is recommended for use in daily practice. Our study, therefore, encourages additional investigation of this biomarker. Finally, the limited value of specificity and positive predictive value of serum CC16 for predicting deterioration of pulmonary function or death $(0.65$ and 0.57 , respectively) might be due to some confounding factors that were not controlled and/or adjusted in our study such as diurnal variation ${ }^{27}$, atopic status ${ }^{28}$, exercise ${ }^{29}$, and inhaled pollutant ${ }^{30}$. These factors if present might contribute to increase the serum $\mathrm{CC} 16$ even if patients did not worsen their SSc-related pulmonary fibrosis. These factors should be well controlled in future studies investigating $\mathrm{CC} 16$ as a biomarker of chronic lung diseases in general and SSc-related ILD in particular.

Our findings showed that baseline serum $\mathrm{CC} 16$ has a significant predictive value for worsening of lung disease in patients with SSc. Further studies are needed to show whether serum CC16 could be used in association with other pneumoproteins to obtain a better predictive value in SSc and other chronic pulmonary diseases ${ }^{31}$.

\section{REFERENCES}

1. Gabrielli A, Avvedimento EV, Krieg T. Scleroderma. N Engl J Med 2009;360:1989-2003.

2. Tyndall AJ, Bannert B, Vonk M, Airò P, Cozzi F, Carreira PE, et al. Causes and risk factors for death in systemic sclerosis: a study from the EULAR Scleroderma Trials and Research (EUSTAR) database. Ann Rheum Dis 2010;69:1809-15.

3. Hua-Huy T, Dinh-Xuan AT. Cellular and molecular mechanisms in the pathophysiology of systemic sclerosis. Pathol Biol 2015; 63:61-8.

4. Volkmann ER, Tashkin DP. Treatment of systemic sclerosis-related interstitial lung disease: a review of existing and emerging therapies. Ann Am Thorac Soc 2016;13:2045-56.

5. Tiev KP, Rivière S, Hua-Huy T, Cabane J, Dinh-Xuan AT. Exhaled NO predicts cyclophosphamide response in scleroderma-related lung disease. Nitric Oxide 2014;40:17-21.

6. Roth MD, Tseng CH, Clements PJ, Furst DE, Tashkin DP, Goldin JG, et al; Scleroderma Lung Study Research Group. Predicting treatment outcomes and responder subsets in scleroderma-related interstitial lung disease. Arthritis Rheum 2011;63:2797-808.

7. Kranenburg P, van den Hombergh WM, Knaapen-Hans HK, van den Hoogen FH, Fransen J, Vonk MC. Survival and organ involvement in patients with limited cutaneous systemic sclerosis and anti-topoisomerase-I antibodies: determined by skin subtype or auto-antibody subtype? A long-term follow-up study. Rheumatology 2016;55:2001-8.

8. Markusse IM, Meijs J, de Boer B, Bakker JA, Schippers HPC, Schouffoer AA, et al. Predicting cardiopulmonary involvement in patients with systemic sclerosis: complementary value of nailfold

Personal non-commercial use only. The Journal of Rheumatology Copyright @ 2018. All rights reserved. 
videocapillaroscopy patterns and disease-specific autoantibodies. Rheumatology 2017;56:1081-8.

9. Hamaguchi Y. Autoantibody profiles in systemic sclerosis: predictive value for clinical evaluation and prognosis. J Dermatol 2010;37:42-53.

10. Tiev KP, Hua-Huy T, Kettaneh A, Allanore Y, Le-Dong NN, Duong-Quy S, et al. Alveolar concentration of nitric oxide predicts pulmonary function deterioration in scleroderma. Thorax 2012;67:157-63.

11. Tiev KP, Hua-Huy T, Kettaneh A, Gain M, Duong-Quy S, Tolédano $\mathrm{C}$, et al. Serum CC chemokine ligand-18 predicts lung disease worsening in systemic sclerosis. Eur Respir J 2011;38:1355-60.

12. Broeckaert F, Clippe A, Knoops B, Hermans C, Bernard A. Clara cell secretory protein (CC16): features as a peripheral lung biomarker. Ann N Y Acad Sci 2000;923:68-77.

13. Tsoumakidou M, Bouloukaki I, Thimaki K, Tzanakis N, Siafakas NM. Innate immunity proteins in chronic obstructive pulmonary disease and idiopathic pulmonary fibrosis. Exp Lung Res 2010;36:373-80.

14. Hermans C, Petrek M, Kolek V, Weynand B, Pieters T, Lambert M, et al. Serum Clara cell protein (CC16), a marker of the integrity of the air-blood barrier in sarcoidosis. Eur Respir J 2001;18:507-14.

15. Petersen H, Leng S, Belinsky SA, Miller BE, Tal-Singer R, Owen $\mathrm{CA}$, et al. Low plasma CC16 levels in smokers are associated with a higher risk for chronic bronchitis. Eur Respir J 2015;46:1501-3.

16. Guerra S, Halonen M, Vasquez MM, Spangenberg A, Stern DA, Morgan WJ, et al. Relation between circulating CC16 concentrations, lung function, and development of chronic obstructive pulmonary disease across the lifespan: a prospective study. Lancet Respir Med 2015;3:613-20.

17. Hasegawa M, Fujimoto M, Hamaguchi Y, Matsushita T, Inoue K, Sato $\mathrm{S}$, et al. Use of serum clara cell $16-\mathrm{kDa}(\mathrm{CC} 16)$ levels as a potential indicator of active pulmonary fibrosis in systemic sclerosis. J Rheumatol 2011;38:877-84.

18. Olewicz-Gawlik A, Trzybulska D, Kuznar-Kaminska B, Katulska K, Danczak-Pazdrowska A, Batura-Gabryel H, et al. Serum Clara cell 16-kDa protein levels and lung impairment in systemic sclerosis patients. Rev Bras Reumatol Engl Ed 2016;56:309-13.

19. Preliminary criteria for the classification of systemic sclerosis (scleroderma). Subcommittee for scleroderma criteria of the American Rheumatism Association Diagnostic and Therapeutic Criteria Committee. Arthritis Rheum 1980;23:581-90.

20. Miller MR, Hankinson J, Brusasco V, Burgos F, Casaburi R, Coates A, et al; ATS/ERS Task Force. Standardisation of spirometry. Eur Respir J 2005;26:319-38.
21. Travis WD, Costabel U, Hansell DM, King TE Jr, Lynch DA, Nicholson AG, et al; ATS/ERS Committee on Idiopathic Interstitial Pneumonias. An official American Thoracic Society/European Respiratory Society statement: Update of the international multidisciplinary classification of the idiopathic interstitial pneumonias. Am J Respir Crit Care Med 2013;188:733-48.

22. Raghu G, Collard HR, Egan JJ, Martinez FJ, Behr J, Brown KK, et al. An official ATS/ERS/JRS/ALAT statement: idiopathic pulmonary fibrosis: evidence-based guidelines for diagnosis and management. Am J Respir Crit Care Med 2011;183:788-824.

23. Wells AU. Forced vital capacity as a primary end point in idiopathic pulmonary fibrosis treatment trials: making a silk purse from a sow's ear. Thorax 2013;68:309-10.

24. Assassi S, Sharif R, Lasky RE, McNearney TA, Estrada-Y-Martin RM, Draeger H, et al; GENISOS Study Group. Predictors of interstitial lung disease in early systemic sclerosis: a prospective longitudinal study of the GENISOS cohort. Arthritis Res Ther 2010;12:R166.

25. Hant FN, Ludwicka-Bradley A, Wang HJ, Li N, Elashoff R, Tashkin DP, et al; Scleroderma Lung Study Research Group. Surfactant protein D and KL-6 as serum biomarkers of interstitial lung disease in patients with scleroderma. J Rheumatol 2009;36:773-80.

26. Elhaj M, Charles J, Pedroza C, Liu X, Zhou X, Estrada-Y-Martin $\mathrm{RM}$, et al. Can serum surfactant protein D or CC-chemokine ligand 18 predict outcome of interstitial lung disease in patients with early systemic sclerosis? J Rheumatol 2013;40:1114-20.

27. Helleday R, Segerstedt B, Forsberg B, Mudway I, Nordberg G, Bernard A, et al. Exploring the time dependence of serum clara cell protein as a biomarker of pulmonary injury in humans. Chest 2006;130:672-5.

28. Benson M, Fransson M, Martinsson T, Naluai AT, Uddman R, Cardell LO. Inverse relation between nasal fluid Clara Cell Protein 16 levels and symptoms and signs of rhinitis in allergen-challenged patients with intermittent allergic rhinitis. Allergy 2007;62:178-83.

29. Nanson CJ, Burgess JL, Robin M, Bernard AM. Exercise alters serum pneumoprotein concentrations. Respir Physiol 2001; 127:259-65.

30. Broeckaert F, Arsalane K, Hermans C, Bergamaschi E, Brustolin A, Mutti A, et al. Serum clara cell protein: a sensitive biomarker of increased lung epithelium permeability caused by ambient ozone. Environmental Health Perspectives 2000;108:533-7.

31. Lakind JS, Holgate ST, Ownby DR, Mansur AH, Helms PJ, Pyatt D, et al. A critical review of the use of Clara cell secretory protein (CC16) as a biomarker of acute or chronic pulmonary effects. Biomarkers 2007;12:445-67. 